\title{
COMMUNITIES OF PRACTICE IN HIGHER EDUCATION
}

\author{
Marijke Hezemans and Magda Ritzen \\ Hogeschool van Utrecht, University for Professional Education and Applied Science, Utrecht, \\ the Netherlands: CETIS, Expert Centre for Educational Innovation and Training \\ m.hezemans@cetis.hvu.nl and m.ritzen@cetis.hvu.nl
}

\begin{abstract}
Internal and external developments in higher education are leading to transformation of education being placed high on the agenda. This places a great burden on the professionalisation of the staff. In a previous article (Hezemans and Ritzen, 2004) we described the way in which professionals learn and innovate. Communities of Practice ( $\mathrm{CoPs})$ were introduced as a 'new' way to learn. In this article we further zoom in on the phenomenon CoP: what are CoPs, what are the success-factors and how can this way of learning and working together contribute to innovation in higher education.
\end{abstract}

Key words: Professional development, community of practice, on-the-job training, higher education, life-long learning.

\section{INTRODUCTION}

Academic universities and universities of professional education are currently in the midst of modernising their education to better suit the demands of present and future students. Higher education is becoming more vocational and occupationally-orientated: there is more and more interest in (learning) the application of theories and concepts. This requires a new approach in the coaching of learning processes. Demand-driven, the exchange of experiences and collaborative learning (community-learning) seem to be promising elements when giving shape to modernisation.

This paper describes a way of learning and working when giving shape to educational innovations, given our experiences within the University for Professional Education and Applied Science, Utrecht, the Netherlands. The 
stronger aspects of the phenomenon community-learning, that has caught on in recent years (also in the business world) are included. First a description of a Community of Practice is given. Learning in a CoP, by definition, is directly related to the personal work-environment, the 'practice' of the participant. Furthermore (learning-) benefits for both organisation and individual are sketched. In conclusion, on the basis of experiences within our university, a number of success-factors are put forward, which can promote collaborative learning and working in a community.

\section{WHAT IS A COMMUNITY OF PRACTICE?}

A CoP is a group of people who share a (great) interest in a certain subject or theme. They meet to exchange, develop and make explicit knowledge, which arises from questions and problems they have (Wenger, McDermott \& Snyder, 2002). CoPs can be initiated by individual staff members, experts or by teams (for example, after completion of a project) and exist thanks to the 'give and take' attitude of the participants. Participants are usually active: formulating a problem or learning-question, giving feedback, asking questions, giving tips or answers, supplying literature, etc.

CoPs can differ in method of working (formal with agendas or informal), accessibility (open/closed) and size. These aspects are related to the extent to which it is important to know one another (trust) and the wish to cooperatively - as a community - apart from sharing experiences, also develop knowledge. Knowledge-development requires trust and this best grows in a small community or in a secluded part of a larger community.

CoPs are in reality their own clients, the participants adopting an open attitude towards each other, with self-organisation forming the basis of the CoPs activities. There are 'free' communities (cooperative relationships, networks, mailing lists etc.) and CoPs which adopt an official relationship with the organisation (sponsored or business-related CoPs). Members of a $\mathrm{CoP}$ can, with or without a request by an external body (for example the management), take on a certain job. The members of such a business-related $\mathrm{CoP}$ find it fun and useful to work on self-chosen/accepted assignments and by doing so make a direct contribution to the organisation. Such a contribution can in this case be considered an 'educational innovation'.

CoPs know (ideally) three stages of development: individual knowledge sharing, communally making knowledge explicit and communal creation of new knowledge (Andriessen, 2003). Some communities start directly with the ambition of communally creating new knowledge and thereby give shape to educational innovation. In other communities only after a certain passage 
of time will it become clear that there is a demand for knowledgedevelopment or that sharing experiences is sufficient (for example cooperative relationships, networks, interest group, themed-site, research group, special interest group).

What distinguishes a CoP is that learning occurs in parallel on three different levels: with respect to the content, socially and with respect to the process. Along with the discovery and development of effective approaches and processes, the mutual solidarity with the community grows and the members find better ways of exchanging and combining knowledge (Bood $\&$ Coenders, 2004). CoPs differ in this regard to project-teams: in a projectteam it is the (quality of the) result that matters.

CoPs are shaped by the members and the goals. There are few 'hard' golden rules that can be given. There are, however, important success-factors to be taken into account; these are elaborated upon later on.

\section{COP'S AND THEIR BENEFITS}

Communities ought to have a place in every learning organisation. Organisations that support learning score highly on two dimensions (Dankbaar \& Oprins, 2002):

1. Organisational dimension: the extent to which the structure and culture of the organisation support and stimulate learning, for example via a clear mission through which learning-processes gain a focus, management offering solid support for methods such as coaching and reflection, being open-minded towards new ideas.

2. Personal dimension: the extent to which staff are self-confident, motivated and able to learn. This can be seen in an open-minded attitude and a willingness to learn.

If both the organisational and personal dimensions turn out to be positive then there is a safe environment within which staff can cooperatively learn from experiences and new ideas can be formed, focussed on the mission and strategy of the organisation. Whenever people come together in the context of their work with such an open-minded attitude, the organisation as a whole benefits. This benefit can be implicit (people help each other) or explicit (shape is given to innovations, new style education in such a way that others are also able to benefit).

In the table below the benefits for the individual and educational organisation are sketched. Examples of CoPs in the University for Professional Education and Applied Science, Utrecht, the Netherlands illustrate these benefits. 
Table 1: Benefits of CoPs for individuals and educational organisations

\begin{tabular}{|c|c|c|}
\hline & \\
\hline & Short term benefits & Long term benefits \\
\hline & $\begin{array}{l}\text { Optimisation of the learning- } \\
\text { environment }\end{array}$ & Educational innovation \\
\hline \multirow[t]{2}{*}{$\begin{array}{l}\text { Benefits for the } \\
\text { organisation }\end{array}$} & 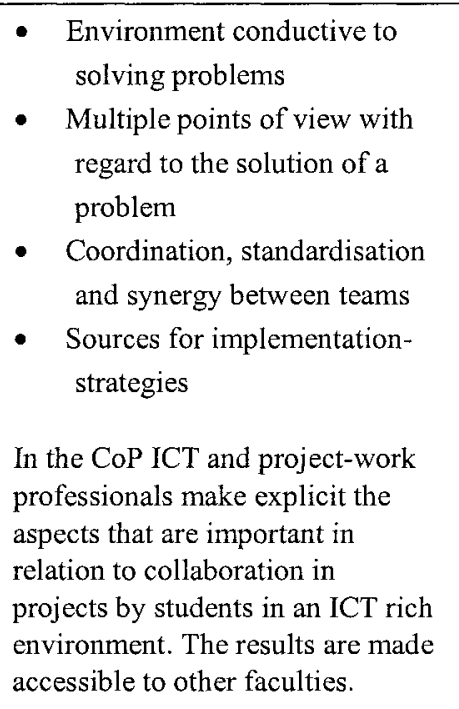 & $\begin{array}{l}\text { - } \quad \text { Retaining talent } \\
\text { - Capacity for knowledge- } \\
\text { development projects } \\
\text { - Capacity for developing new } \\
\text { strategies } \\
\text { undising visibility of } \\
\text { undiscovered talent } \\
\text { A faculty of our university wants } \\
\text { to introduce a portfolio in } 2003 \text {. } \\
\text { The CoP student-mentorship and } \\
\text { portfolio is asked to make a } \\
\text { contribution. }\end{array}$ \\
\hline & Raising the quality of work & Innovation by the profession \\
\hline \multirow[t]{2}{*}{$\begin{array}{l}\text { Benefits for } \\
\text { community } \\
\text { member }\end{array}$} & $\begin{array}{l}\text { - Help with challenges } \\
\text { - Access to a source of expertise } \\
\text { - Taking enjoyment from } \\
\text { working with colleagues } \\
\text { - The feeling of belonging to } \\
\text { something }\end{array}$ & $\begin{array}{l}\text { - Platform for dissemination of } \\
\text { skills and expertise } \\
\text { - Fortification of professional } \\
\text { reputation } \\
\text { - Fortification of professional } \\
\text { identity }\end{array}$ \\
\hline & $\begin{array}{l}\text { Professionals in the CoP } \\
\text { Instruments of our university give } \\
\text { each other feedback on modules } \\
\text { that they have developed in a } \\
\text { digital environment. }\end{array}$ & $\begin{array}{l}\text { In the CoP professional coaches } \\
\text { develop a coaching and } \\
\text { assessment model, which they also } \\
\text { make known to colleagues. }\end{array}$ \\
\hline
\end{tabular}

\section{SUCCESS-FACTORS COMMUNITIES OF PRACTICE}

Within our university there is gradual recognition of the importance of communities in educational innovation: managers approach communities for advice on policy. Staff functioning in multidisciplinary teams seek out communities, depending on their learning needs. They find it helpful to 
exchange experiences and develop new solutions with colleagues who share their learning needs. The case below will help illustrate the way in which community-forming is stimulated within the university ( $\mathrm{HvU})$.

\subsection{HvU-Case: Development of Professionals and Innovation}

- Background. In March 2003 a conference about innovating education and ICT was held for the second time. At the conference staff and students from various faculties showed the different uses they make of ICT. During the conference everyone is very enthusiastic and full of good intentions to meet again after the conference. Usually this does not happen. For this reason the conference commission decided to follow-up the conference with community of practice (CoPs) gatherings.

- Initiative. The conference was arranged according to eight themes. Each theme was prepared and chaired by a chairperson. As part of the preparation the chairperson would gauge the level of interest the presenters had in a CoP on 'their' theme. During the conference sessions it was announced that the sessions would be followed-up by CoPs, and the planned kick-off dates were given. Additional questions were collected and would be used as input for the CoP. On the basis of registrations it was decided that four of the eight CoPs would go ahead. These were the four CoPs that were most clearly related to education: 'Testing and Assessment', 'Student coaching and Portfolio', 'Instruments in Education' and 'ICT and project-based education'. CoPs such as 'wireless' and 'quality assurance' were dropped due to lack of interest.

- Facilitation. Measures needed to support the CoPs could be realised within the framework of the Information Policy Plan: the theme chair people (content moderators) and 'pullers' (organisers and CoP-experts) could claim a part of their hours. Catering and room hire were payed for by the 'hosts'. IT-support by Lotus Quickplace was - till $1^{\text {st }}$ January 2004 - made possible by the IT department. The chair people and 'pullers' met in the interim periods to exchange experiences and to look at whether the current arrangement of CoPs (domains) was still relevant.

- Way of working. Most of the CoPs have approximately eight participants and meet regularly (once every six weeks). Two CoPs had a communal question right from the start (e.g. how can a project-based approach to problems / assignments be best supported by ICT), one CoP decided to let their agenda be composed of participants' questions and another $\mathrm{CoP}$ had such a diverse set of questions that progress was severely hampered and eventually only 7 out of 15 participants 
remained. This CoP did manage to book communal results, but there is little remaining drive.

- Benefits. The participants (staff members) continue to find it worthwhile to attend CoP meetings. They meet, and can consult, people who are working on the same things they are. In all the CoPs problems are discussed and experiences are exchanged, in a few CoPs an attempt is made to make explicit knowledge and ideas (e.g. what are the characteristics of project-based teaching) so that others may also benefit. In this way the CoPs play an important role in the professionalisation of participants and satisfy important success criteria: demand-driven, to the point and on the job.

- The future. The evaluation of the CoPs has now taken place. The participants indicate that they found the CoPs beneficial for their work, but that they could be even more beneficial through measures such as: rotating chairpersonship, more accurate description of the domain, merging of CoPs, expansion of participancy through organisation-wide announcement of meetings (promotion), more focus in the agenda, more attention for formulating joint results. The management is also satisfied by the early results and has signalled their intention to reserve money for the expansion and support of the experiment. This support is constituted by a web-site where materials are (made) available which facilitate the $\mathrm{CoP}$ process and virtual rooms which can be reserved by the CoPs. Alongside these measures there are also plans for a coordinating $\mathrm{CoP}$ which will advise on the CoP process.

\subsection{Success-Factors}

On the basis of the experiences within our university the following success-factors have been identified (Wenger, 2002, Römgens, 2001 and McDermott, 2001):

- Organise preliminary activities, for example seminars or congresses, so that professionals have the opportunity to meet one another and indicate their communal interest in certain themes or subjects.

- Start with a small group of people who already meet on a regular basis in relation to work problems or themes (existing informal groups). A small core group increases the chance of mutual trust, and an open atmosphere is an important criterion for sharing knowledge.

- Appoint a coordinator of the CoP. This role is very important. He/she talks regularly to various members and makes contact with potential members. In this way the coordinator always has a good picture of what the biting issues are which need to be tackled in order to keep the community alive. 
- Give the CoPs a place in the organisation, for example by formalising their role in a policy or professionalisation plan with matching budget.

- Organise a coordinating community, which has and develops expertise in relation to the import of CoPs for organisation and individual, knowledge management and the coaching of communities. This is especially of import in the start-up phase: the coordinating community is knowledgeable about the world of communities, can gear activities to one another and is up to speed on the activities and themes within the various CoPs in the organisation. The community combines (external) expertise with (internal) lessons learned and uses these to develop knowledge about creating and maintaining successful CoPs.

- Raise the question of the benefit of the CoP regularly within the CoP itself: What benefits does the CoP yield as a community/group?; How does the $\mathrm{CoP}$ benefit the organisation? The value can be visible (in documents) or invisible (trust and ability to innovate, feeling of belonging, spirit of enquiry). A CoP that doesn't yield any benefits for the respective individuals will not take-off.

- Try to link the community in to the work situation and work related problems the participants have. Sharing a communal issue ensures that it is fruitful to work on problems together (on the job and to the point).

$\mathrm{CoPs}$ are for and by the participants and originate in a bottom-up manner. But just like a 'wild' garden cultivation, care and attention have a positive influence. The way in which the organisation carries out this cultivation can vary greatly and depends on the type of, and innovative character of, said organisation. Certain organisations strongly steer towards the form and setup of a CoP, for example a company such as Unilever that needs new products in order to survive is therefore greatly benefited by 'innovative' communities. But there are also organisations that only create the minimally required preconditions and master the art of working, learning and innovating collaboratively as they go: educational organisations seem to be best catered for by bottom-up initiatives and top-down facilitation (Beijering et al. 2002).

\section{CONCLUSION: COPS AS SEEN BY PROFESSIONAL AND ORGANISATION}

Above we provided a description of what Communities of Practice are, what benefits they bring for individual and educational organisation and which success-factors can improve learning and working in communities. Communities of Practice can play an important role in the exchange, development and making explicit of new knowledge. A CoP can be a place 
where the innovative energy of an organisation is bundled: communities then perform an important role in adding value to the process of making the strategic policy operational and creating new and innovative solutions. To make this possible the organisation must accommodate the formation of CoPs: it must have faith in the professionalism of its staff; a culture which creates challenges and chances, but also places demands on the professional development of its employees, including management (van Emst, 1999).

An organisation that wants to grow into a learning organisation would be wise to stimulate and cherish the development of CoPs (from communitylike initiatives to innovative CoPs).

The experiences of our university show that Communities of Practice actually are important in the exchange, development and making explicit of new knowledge. HvU-communities perform more and more an important role in adding value to the process of making the strategic policy operational and creating new and innovative solutions. Our communities offer staff a way to both work and learn whilst also shaping educational innovation.

\section{REFERENCES}

Andriessen, J.H.E. (2003). Kennisnetwerken. In: Opleiding \& Ontwikkeling, 3, pp. 27-31.

Beijering, J. e.a. (2002). Eindrapport Virtueel Kenniscentrum en expertisenetwerken: opbouw en verspreiding van expertise. Digitale Universiteit, http://www.digiuni.nl

Bood, R. en M. Coenders (2004). Communities of Practice. Utrecht: LEMMA BV.

Dankbaar, M.E.W. en E.A.P.B. Oprins. (2002). Kennismanagement: ervaringskennis delen in werkomgevingen Opleiding \& Ontwikkeling, 10, pp. 13-18.

Hezemans, M.G.O., \& M.M.J. Ritzen, (2004)., The teacher: from a responsible student's point-of-view. In: P. Nicholson, B. Thomson, M. Ruohenen \& J. Multisilta (eds), Etraining practices for professional organisations. Boston/Dordrecht/London: Kluwer Academic Publishers.

McDermott, R. (2001). Knowing in Community: 10 Critical Success Factors in Building Communities of Practice, http://www.co-I-l.com/coil/knowledge-garden/cop/knowing.shtml

Römgens, B. (2002), Instrumenten voor Communities, CIBIT, interne publicatie.

Shaffer, R., Koehn, D., Creating Communities of Practice - The Knowledge Bridge Builders, juni 2002, http://www.rgsinc.com/publications/pdf/white_papers/Communities of Practice.pdf

van Emst, Alex (1999). Professionele cultuur in onderwijsorganisaties, Utrecht: APS/Edukern

Wenger, E. McDermott, R. en Snyder, W.M. (2002). Cultivating CoP's, A guide to managing knowledge. Harvard Business School press, Boston Massachusetts.

Wenger, E., (2001) Supporting communities of practice, a survey of community-oriented technologies, versie 1.3 , Shareware, www.ewenger.com/tech 